\title{
32. INTERSTITIAL WATER AND MINERALOGICAL STUDIES, LEG 41
}

\author{
Rex Couture, Randall S. Miller, and Joris M. Gieskes, Scripps Institution of Oceanography, La Jolla, California
}

\begin{abstract}
Onboard and subsequent analyses of the chemical composition of the interstitial waters collected during Leg 41 indicate that evaporite beds are responsible for observed chlorinity increases in Sites 369 and 370 . Sulfate reduction processes in all drilled sites have led to low dissolved sulfate concentrations. All sites indicate complicated patterns in concentration changes of calcium, magnesium, and strontium. The latter are probably related to carbonate recrystallization processes.
\end{abstract}

\section{INTRODUCTION}

During Leg 41 , sites were drilled in the vicinity of some Leg 14 sites that showed evidence from interstitial water chlorinity data of evaporites underlying the deepest cored sediments. Shipboard data did indeed show well-defined chlorinity gradients at Sites 369 and 370 . With this information and our interest in mapping the major ion gradients in deep-sea drill holes, we decided to follow up the shipboard work on the chemistry of the interstitial waters by more elaborate chemical analyses. Since Leg 14 studies indicated high concentrations of palygorskite in this area, we were also interested in determining the distribution of palygorskite and sepiolite and in relating them to the interstitial water compositions. The various sites drilled are indicated in Figure 1, in addition to sites drilled during Leg 14.

\section{METHODS}

Shipboard interstitial water analyses consisted of routine $p \mathrm{H}$ and alkalinity measurements, as well as determinations of calcium, magnesium, chloride, and salinity. The shipboard titration data for calcium and magnesium have been corrected for matrix effects (Gieskes and Lawrence, 1976) as well as for strontium. In our laboratory, we determined concentrations of strontium, potassium, manganese, sulfate, ammonia, and dissolved silica, using procedures similar to those of Gieskes (1974).

We made qualitative X-ray diffraction analyses of samples mounted on glass slides. The region from $2-14^{\circ}$ $2 \theta$ was scanned to determine clays. Most samples were also analyzed for carbonate minerals, and some of these analyses were confirmed by acid dissolution. The samples containing expandable minerals were glycolated, and high carbonate samples were decalcified with an acetate buffer $(p \mathrm{H}=5)$.

\section{RESULTS}

All data obtained on the interstitial waters are presented in Table 1 and Figures 2 to 6 . Mineral data are given in Table 2. Some samples consist almost entirely of palygorskite, sepiolite, or both.

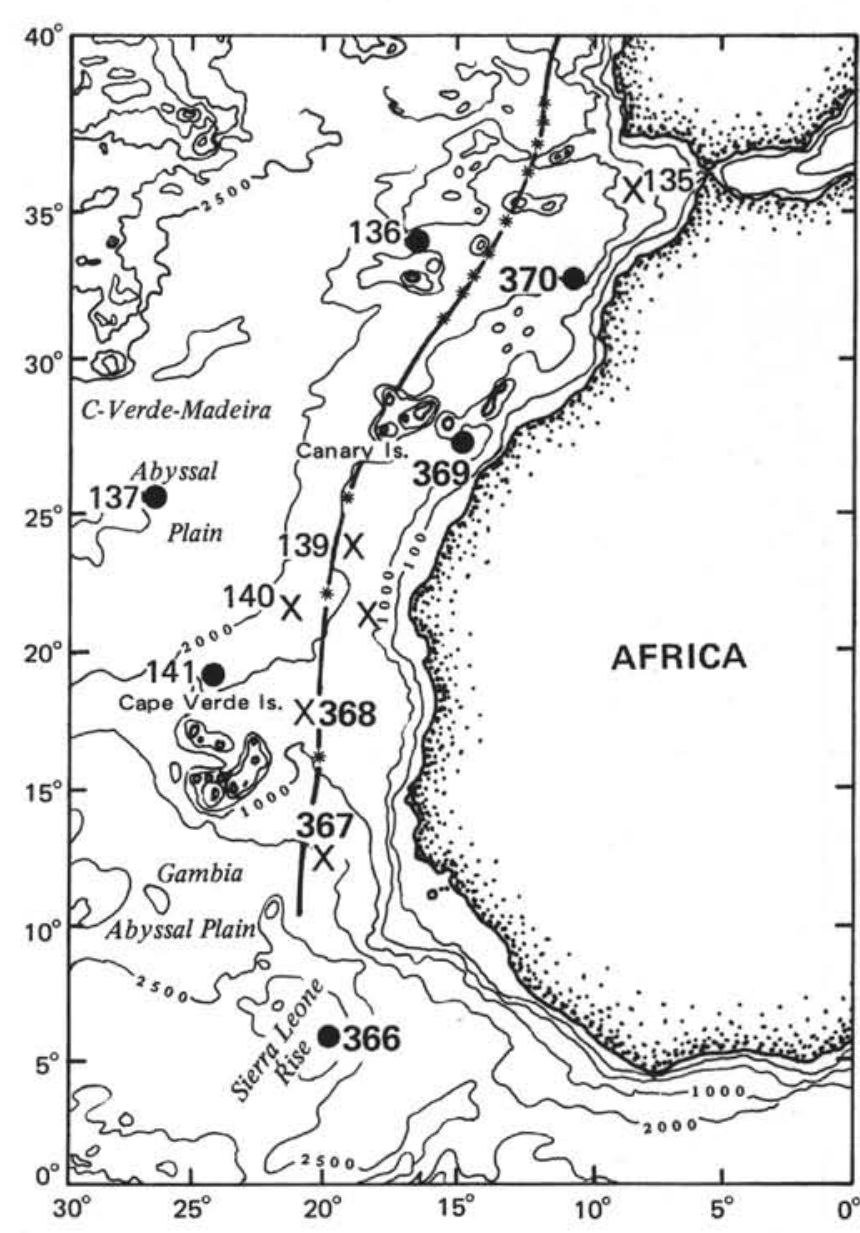

Figure 1. Station locations. Sites marked with dots show a continuous increase with depth in dissolved calcium; sites with crosses show initial decreases in dissolved calcium.

\section{DISCUSSION}

Interstitial waters from Sites 139 and 140 of Leg 14 (Waterman et al., 1972) and from Sites 369 and 370 clearly reveal the presence of increasing concentrations of chlorinity and salinity with depth. The increases, although distinct, are relatively small compared to 
TABLE 1

Chemical Composition of Interstitial Water, Leg 41

\begin{tabular}{|c|c|c|c|c|c|c|c|c|c|c|c|c|c|}
\hline $\begin{array}{c}\text { Sample } \\
\text { (Interval in cm) }\end{array}$ & $\begin{array}{l}\text { Depth } \\
\text { (m) }\end{array}$ & $p \mathrm{H}^{\mathrm{a}}$ & $\begin{array}{c}\mathrm{Alk}^{\mathrm{a}} \\
(\mathrm{meq} / 1)\end{array}$ & $\begin{array}{c}s^{a} \\
(\% \circ)\end{array}$ & $\begin{array}{c}\mathrm{Cl}^{\mathrm{a}} \\
(\% \circ)\end{array}$ & $\begin{array}{c}\mathrm{Ca}^{\mathrm{a}} \\
(\mathrm{mmoles} / 1)\end{array}$ & $\begin{array}{c}\mathrm{Mg}^{\mathrm{a}} \\
\text { (mmoles/1) }\end{array}$ & $\begin{array}{c}\mathrm{Sr} \\
\text { (mmoles/1) }\end{array}$ & $\underset{(\mathrm{mmoles} / 1)}{\mathrm{K}}$ & $\begin{array}{c}\mathrm{Mn} \\
(\mathrm{ppm})\end{array}$ & $\underset{\text { (mmoles/1) }}{\mathrm{SO}_{4}}$ & $\underset{(\mu \text { moles } / 1)}{\mathrm{NH}_{4}}$ & $\underset{\left(\mu \mathrm{moles}_{2} / 1\right)}{\mathrm{SiO}_{2}}$ \\
\hline \multicolumn{14}{|l|}{ Site 366} \\
\hline $\begin{array}{l}1-2,0-6 \\
3-5,0-6 \\
4-2,144-150 \\
5-5,142-150 \\
10-4,144-150 \\
15-2,0-10 \\
20-1,145-150\end{array}$ & $\begin{array}{r}1.5 \\
131.5 \\
248.5 \\
373.5 \\
419.5 \\
462.5 \\
510.0\end{array}$ & $\begin{array}{l}7.30 \\
6.85 \\
6.79 \\
6.78 \\
7.07 \\
6.82 \\
6.85\end{array}$ & $\begin{array}{l}3.43 \\
4.90 \\
5.82 \\
5.42 \\
4.22 \\
4.47 \\
0.60\end{array}$ & $\begin{array}{l}35.2 \\
35.5 \\
35.8 \\
36.0 \\
35.0 \\
36.3 \\
36.0\end{array}$ & $\begin{array}{l}19.2 \\
19.1 \\
18.0 \\
19.4 \\
19.3 \\
19.3 \\
19.1\end{array}$ & $\begin{array}{l}11.6 \\
19.0 \\
23.0 \\
25.6 \\
31.8 \\
32.9 \\
40.2\end{array}$ & $\begin{array}{l}51.8 \\
45.7 \\
43.6 \\
40.4 \\
34.5 \\
34.4 \\
26.1\end{array}$ & $\begin{array}{l}.08 \\
0.51 \\
0.66 \\
0.75 \\
0.95 \\
0.99 \\
1.23\end{array}$ & $\begin{array}{r}11.6 \\
11.0 \\
9.7 \\
10.5 \\
8.9 \\
7.7 \\
7.2\end{array}$ & $\begin{array}{l}1.5 \\
0.1 \\
0.1 \\
0.1 \\
0 \\
0 \\
0.1\end{array}$ & $\begin{array}{c}29.5 \\
28.9 \\
26.6 \\
25.4 \\
-. \\
22.7 \\
\cdots\end{array}$ & $\begin{array}{r}46 \\
212 \\
285 \\
347 \\
668 \\
390 \\
685\end{array}$ & $\begin{array}{r}499 \\
307 \\
867 \\
620 \\
1123 \\
1018 \\
650\end{array}$ \\
\hline \multicolumn{14}{|l|}{ Site 366A } \\
\hline $\begin{array}{r}1-3,144-150 \\
5-4,144-150 \\
9-5,144-150 \\
14-5,144-150 \\
20-2,144-150 \\
26-3,144-150\end{array}$ & $\begin{array}{r}4.5 \\
40.5 \\
80.0 \\
127.5 \\
180.0 \\
238.5\end{array}$ & $\begin{array}{l}7.52 \\
7.13 \\
7.03 \\
6.93 \\
6.84 \\
6.76\end{array}$ & $\begin{array}{l}3.22 \\
4.06 \\
4.70 \\
5.98 \\
6.47 \\
6.99\end{array}$ & $\begin{array}{l}35.2 \\
35.8 \\
35.8 \\
36.0 \\
36.0 \\
36.3\end{array}$ & $\begin{array}{l}19.5 \\
19.7 \\
20.0 \\
19.8 \\
19.8 \\
20.1\end{array}$ & $\begin{array}{l}11.3 \\
13.2 \\
15.4 \\
19.3 \\
22.7 \\
26.8\end{array}$ & $\begin{array}{l}53.1 \\
51.9 \\
50.4 \\
48.0 \\
45.7 \\
42.5\end{array}$ & $\begin{array}{l}0.06 \\
0.19 \\
0.32 \\
0.49 \\
0.62 \\
0.74\end{array}$ & $\begin{array}{r}11.2 \\
10.5 \\
9.9 \\
9.6 \\
9.5 \\
8.9\end{array}$ & $\begin{array}{l}1.7 \\
0.1 \\
0 \\
0 \\
0 \\
0.1\end{array}$ & $\begin{array}{l}29.7 \\
28.6 \\
28.2 \\
26.9 \\
26.0\end{array}$ & $\begin{array}{l}108 \\
156 \\
157 \\
238 \\
239 \\
320\end{array}$ & $\begin{array}{l}476 \\
161 \\
126 \\
246 \\
786 \\
937\end{array}$ \\
\hline \multicolumn{14}{|l|}{ Site 367} \\
\hline $\begin{array}{r}1-5,144-150 \\
4-4,144-150 \\
8-4,144-150 \\
14-2,144-150 \\
15-4,144-150 \\
16-5,140-150 \\
18-5,146-150 \\
21-4,144-150 \\
23-1,140-150\end{array}$ & $\begin{array}{r}7.5 \\
69.5 \\
308.5 \\
381.5 \\
479.5 \\
547.5 \\
640.5 \\
698.0 \\
779.0\end{array}$ & $\begin{array}{l}7.46 \\
7.38 \\
7.20 \\
7.40 \\
7.74 \\
-. \\
7.01 \\
7.10 \\
7.46\end{array}$ & $\begin{array}{l}4.68 \\
3.46 \\
8.91 \\
3.36 \\
3.05 \\
2.27 \\
2.52 \\
2.30 \\
1.29\end{array}$ & $\begin{array}{l}34.9 \\
34.9 \\
33.6 \\
32.4 \\
33.0 \\
30.2 \\
32.2 \\
32.2 \\
32.4\end{array}$ & $\begin{array}{l}19.3 \\
19.3 \\
19.3 \\
19.3 \\
19.0 \\
17.6 \\
19.0 \\
19.3 \\
18.9\end{array}$ & $\begin{array}{r}11.3 \\
9.0 \\
14.2 \\
17.5 \\
22.7 \\
24.5 \\
28.2 \\
35.6 \\
44.0\end{array}$ & $\begin{array}{l}52.4 \\
51.4 \\
46.3 \\
42.1 \\
44.1 \\
39.0 \\
40.4 \\
33.3 \\
38.1\end{array}$ & $\begin{array}{l}0.05 \\
0.06 \\
0.16 \\
0.27 \\
0.38 \\
0.46 \\
0.61 \\
0.67 \\
0.65\end{array}$ & $\begin{array}{r}11.7 \\
10.9 \\
7.9 \\
5.3 \\
3.0 \\
2.6 \\
1.9 \\
2.1 \\
1.9\end{array}$ & $\begin{array}{l}2.4 \\
0.3 \\
2.2 \\
1.9 \\
0.2 \\
1.3 \\
0.1 \\
0.4 \\
0\end{array}$ & $\begin{array}{c}30.0 \\
26.4 \\
10.8 \\
6.3 \\
5.2 \\
-- \\
-. \\
4.0 \\
4.0\end{array}$ & $\begin{array}{r}392 \\
417 \\
829 \\
1484 \\
1542 \\
1985 \\
1765 \\
1765 \\
1588\end{array}$ & $\begin{array}{l}459 \\
128 \\
873 \\
591 \\
113 \\
315 \\
220 \\
115 \\
150\end{array}$ \\
\hline \multicolumn{14}{|l|}{ Site 368} \\
\hline $\begin{array}{l}1-4,144-150 \\
3-4,0-6 \\
5-4,144-150 \\
6-5,144-150 \\
8-4,144-150 \\
13-2,144-150 \\
18-5,144-150 \\
23-1,144-150 \\
32-4,144-150 \\
34-2,144-150\end{array}$ & \begin{tabular}{r|}
4.5 \\
51.8 \\
127.8 \\
165.8 \\
184.8 \\
232.3 \\
279.8 \\
355.8 \\
441.3 \\
469.8
\end{tabular} & $\begin{array}{l}7.58 \\
7.41 \\
7.50 \\
7.55 \\
7.61 \\
7.76 \\
8.47 \\
7.92 \\
7.85 \\
7.72\end{array}$ & $\begin{array}{l}3.73 \\
4.40 \\
3.48 \\
3.10 \\
2.55 \\
2.28 \\
2.75 \\
3.75 \\
3.20 \\
2.62\end{array}$ & $\begin{array}{l}35.2 \\
34.6 \\
33.0 \\
32.0 \\
31.9 \\
31.9 \\
32.0 \\
32.2 \\
32.4 \\
32.4\end{array}$ & $\begin{array}{l}20.2 \\
20.0 \\
19.7 \\
19.7 \\
20.3 \\
20.5 \\
19.7 \\
19.5 \\
19.7 \\
19.8\end{array}$ & $\begin{array}{r}10.5 \\
8.5 \\
5.7 \\
5.9 \\
6.2 \\
7.6 \\
9.4 \\
11.5 \\
11.0 \\
10.0\end{array}$ & $\begin{array}{l}51.8 \\
47.8 \\
39.7 \\
35.5 \\
34.7 \\
32.6 \\
30.4 \\
30.1 \\
31.3 \\
33.6\end{array}$ & $\begin{array}{l}0.08 \\
0.17 \\
0.23 \\
0.25 \\
0.25 \\
0.21 \\
0.19 \\
0.20 \\
0.19 \\
0.19\end{array}$ & $\begin{array}{r}10.8 \\
10.1 \\
8.3 \\
8.0 \\
7.7 \\
7.7 \\
8.0 \\
8.1 \\
6.0 \\
6.2\end{array}$ & $\begin{array}{l}1.4 \\
0.1 \\
0.1 \\
0 \\
0 \\
0.45 \\
0.1 \\
0.48 \\
0 \\
0\end{array}$ & $\begin{array}{r}28.7 \\
20.3 \\
7.8 \\
5.0 \\
4.7 \\
3.0 \\
2.7 \\
<1.0 \\
<1.0 \\
<2.5\end{array}$ & $\begin{array}{r}232 \\
389 \\
534 \\
532 \\
520 \\
610 \\
719 \\
1020 \\
1397 \\
1530\end{array}$ & $\begin{array}{l}494 \\
529 \\
149 \\
114 \\
113 \\
373 \\
123 \\
377 \\
428 \\
575\end{array}$ \\
\hline $\begin{array}{l}36-2,144-150 \\
39-5,144-150 \\
46-4,144-150 \\
52-4,144-150\end{array}$ & $\begin{array}{l}517.3 \\
574.3 \\
640.8 \\
726.3\end{array}$ & $\begin{array}{l}7.70 \\
7.61 \\
7.30 \\
8.33\end{array}$ & $\begin{array}{l}2.40 \\
1.69 \\
1.62 \\
1.59\end{array}$ & $\begin{array}{l}32.4 \\
32.0 \\
31.9 \\
31.7\end{array}$ & $\begin{array}{l}19.9 \\
19.9 \\
20.0 \\
19.8\end{array}$ & $\begin{array}{r}9.1 \\
8.9 \\
10.1 \\
12.7\end{array}$ & $\begin{array}{l}36.6 \\
36.5 \\
37.0 \\
36.0\end{array}$ & $\begin{array}{l}0.16 \\
0.17 \\
0.29 \\
0.24\end{array}$ & $\begin{array}{l}5.2 \\
2.8 \\
1.5 \\
1.1\end{array}$ & $\begin{array}{l}0 \\
0 \\
0 \\
0\end{array}$ & $\begin{array}{l}<1.0 \\
<1.0 \\
<1.0 \\
<1.0\end{array}$ & $\begin{array}{l}2110 \\
2500 \\
2450 \\
2820\end{array}$ & $\begin{array}{c}586 \\
339 \\
400 \\
(68)\end{array}$ \\
\hline \multicolumn{14}{|l|}{ Site 369} \\
\hline $\begin{array}{l}1-2,144-150 \\
5-4,144-150\end{array}$ & $\begin{array}{r}3.0 \\
37.5\end{array}$ & $\begin{array}{l}7.39 \\
7.11\end{array}$ & $\begin{array}{l}2.64 \\
6.01\end{array}$ & $\begin{array}{l}35.2 \\
35.5\end{array}$ & $\begin{array}{l}19.5 \\
20.5\end{array}$ & $\begin{array}{l}10.6 \\
12.7\end{array}$ & $\begin{array}{l}53.1 \\
48.9\end{array}$ & $\begin{array}{l}0.07 \\
0.24\end{array}$ & $\begin{array}{l}11.2 \\
10.8\end{array}$ & $\begin{array}{l}0 \\
0\end{array}$ & $\begin{array}{l}30.5 \\
22.7\end{array}$ & $\begin{array}{l}153 \\
632\end{array}$ & $\begin{array}{l}295 \\
376\end{array}$ \\
\hline
\end{tabular}




\begin{tabular}{|c|c|c|c|c|c|c|c|c|c|c|c|c|c|}
\hline \multicolumn{14}{|l|}{ Site 369A } \\
\hline $5-5,144-150$ & 87.5 & 7.02 & 6.69 & 36.2 & 20.8 & 15.0 & 40.0 & 0.43 & 10.2 & 0.1 & 12.3 & 1319 & 713 \\
\hline $10-5,144-150$ & 135. & 6.91 & 9.36 & 36.8 & 22.0 & 14.2 & 38.5 & 0.52 & 8.6 & 0.27 & 3.5 & 1677 & 921 \\
\hline $14-5,144-150$ & 163 & 6.83 & 9.74 & 37.3 & 22.5 & 15.8 & 38.4 & 0.54 & 8.1 & 0.1 & 2.0 & 1871 & 774 \\
\hline $20-5,144-150$ & 230 & 6.78 & 8.50 & 39.0 & 23.6 & 19.4 & 38.8 & 0.65 & 7.3 & 0 & $<2.0$ & 1845 & 803 \\
\hline $25-5.144-150$ & 277.5 & 7.12 & 6.35 & 39.9 & 23.9 & 19.9 & 38.8 & 0.60 & 7.6 & 0.1 & $<2.0$ & 2006 & 589 \\
\hline $30-4,144-150$ & 323.5 & 6.80 & & 40.7 & 24.9 & 21.6 & 39.8 & - & -. & -. & -. & -. & -. \\
\hline $31-5,144-150$ & 334.5 & 6.75 & 6.34 & 41.2 & 25.2 & 22.9 & 40.2 & 0.67 & 6.5 & 0.1 & $<2.0$ & 1960 & 735 \\
\hline $35-3,144-150$ & 369.5 & 6.80 & 5.62 & 43.4 & 27.0 & 24.5 & 42.4 & 0.87 & 6.6 & 0.1 & $<2.0$ & 2061 & 602 \\
\hline $40-2,144-150$ & 415.5 & 6.86 & 4.14 & 46.2 & 28.7 & 26.4 & 45.0 & 1.16 & 5.6 & 0 & $<2.0$ & 2144 & 620 \\
\hline $44-1,144-150$ & 452.0 & 6.94 & 3.40 & 46.3 & 28.0 & 27.3 & 45.4 & 1.08 & 5.0 & 0 & $<2.0$ & 2128 & 413 \\
\hline \multicolumn{14}{|l|}{ Site 370} \\
\hline $1-4,144-150$ & 6 & 7.50 & 2.47 & 35.2 & 17.4 & 10.5 & 51.5 & 0.09 & 11.5 & 0 & -. & 109 & 307 \\
\hline $2-1,144-150$ & 104.5 & 7.21 & 2.41 & 36.0 & 20.6 & 12.9 & 42.6 & 0.37 & 10.6 & 0 & 15.0 & 609 & 170 \\
\hline $3-1,144-150$ & 209 & 7.28 & 2.46 & 36.6 & 21.9 & 15.4 & 36.9 & 0.53 & 9.1 & 0 & 9.7 & 1741 & 789 \\
\hline $5-5,144-150$ & 329 & 8.06 & 1.34 & 39.9 & 24.4 & 22.5 & 30.2 & 0.79 & 7.7 & 0 & $<2.0$ & 1758 & 224 \\
\hline $6-2,144-150$ & 429 & -. & -. & 41.8 & 25.3 & 23.4 & 31.7 & -. & -. & -. & .. & .. & -. \\
\hline $12-2,144-150$ & 543 & -. & 1.26 & 47.6 & 29.2 & 28.4 & 40.6 & -. & $\cdots$ & -. & -. & -. & -. \\
\hline $17-2,144-150$ & 620 & 7.17 & 0.37 & 49.2 & 30.4 & 28.8 & 45.5 & 1.75 & 4.8 & 0.1 & $<3.0$ & 2009 & 788 \\
\hline $20-2,144-150$ & 680 & 7.83 & 0.18 & 49.8 & 31.0 & 35.4 & 39.6 & 2.20 & 3.8 & 0 & -- & 2191 & 100 \\
\hline $25-1,144-150$ & 725 & 7.67 & 0.23 & 50.9 & 31.0 & 36.4 & 42.0 & 2.05 & 3.7 & 0 & -. & 1720 & 134 \\
\hline $30-2,144-150$ & 810 & 7.82 & 0.51 & 58.6 & 36.45 & 48.1 & 45.9 & 2.99 & 4.8 & 0.1 & $<3.0$ & 2008 & 100 \\
\hline $34-3,144-150$ & 880 & 8.02 & 0.22 & 59.4 & 36.2 & 47.1 & 43.7 & 2.96 & 4.4 & 0 & -- & 1682 & 104 \\
\hline $38-4,144-150$ & 945 & 7.79 & 0.18 & 54.7 & 33.3 & 39.9 & 34.1 & 2.97 & 4.6 & 0 & -. & 1535 & 125 \\
\hline $41-4,144-150$ & 995 & 6.62 & 0.12 & 56.7 & 33.9 & 42.3 & 35.9 & 3.10 & 3.6 & 0 & -. & 1215 & 97 \\
\hline $44-2,144-150$ & 1050 & -. & 0.12 & 56.7 & 33.0 & 41.1 & 33.1 & 3.16 & 3.7 & 0 & -. & 1220 & 155 \\
\hline $47-1,144-150$ & 1105 & 7.53 & 0.12 & 55.1 & 36.7 & 43.5 & 33.9 & 3.40 & 3.6 & 0.2 & -. & 1120 & 115 \\
\hline
\end{tabular}

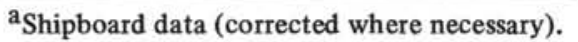


R. COUTURE, R. S. MILLER, J. M. GIESKES
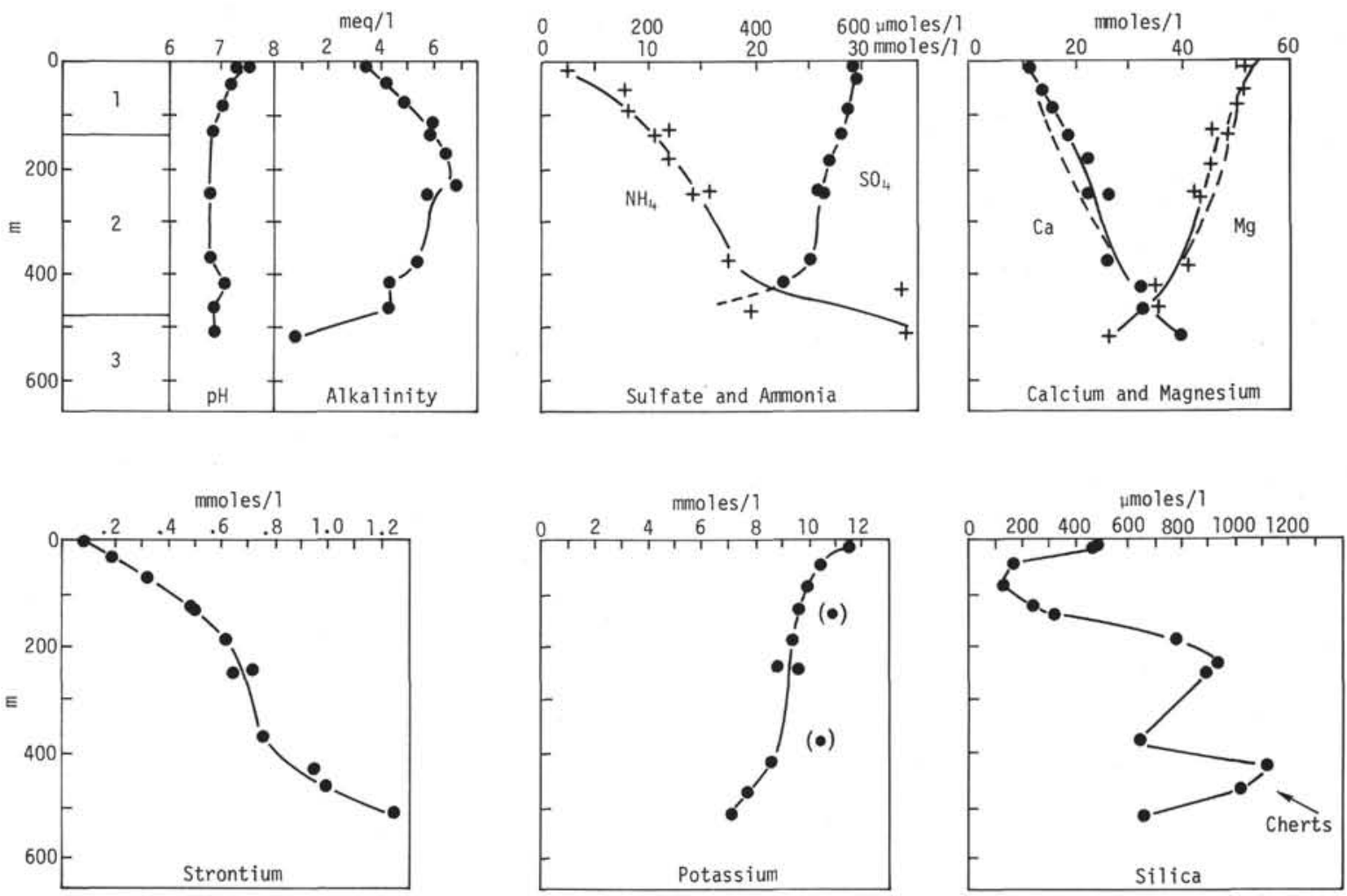

Figure 2. Interstitial water data, Site 366. Lithology: (1) nanno oozes and marls; (2) cyclic nanno oozes or chalks and marls or pelagic clays; (3) cyclic nanno chalks and porcellanites or siliceous limestones.
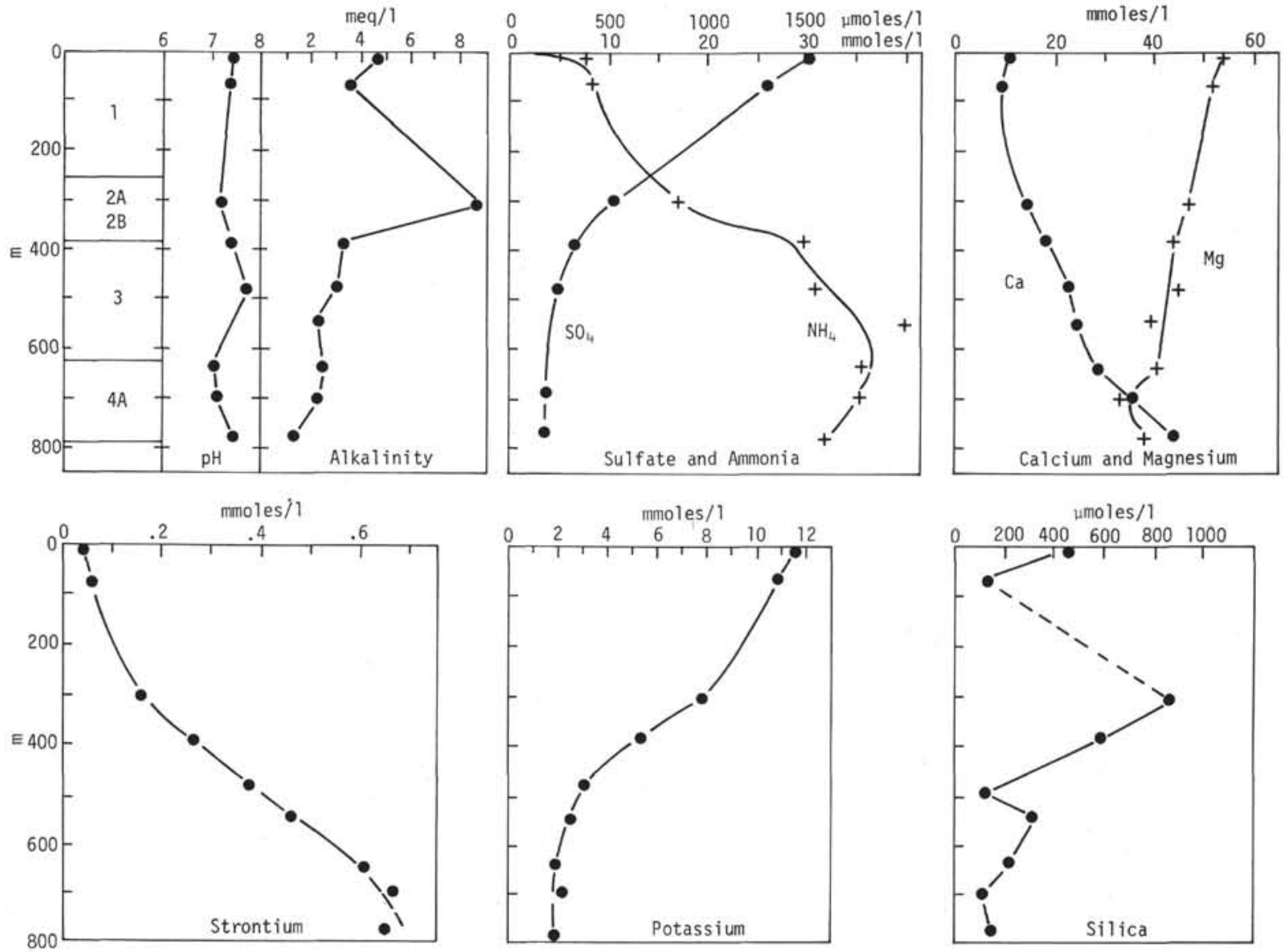

Figure 3. Interstitial water data, Site 367. Lithology: (1) foram-nanno marls with silty clays; (2A) diatom-bearing radiolarian clay; (2B) zeolitic clay with porcellanite; (3) multicolored silty clay; (4) black shale. 

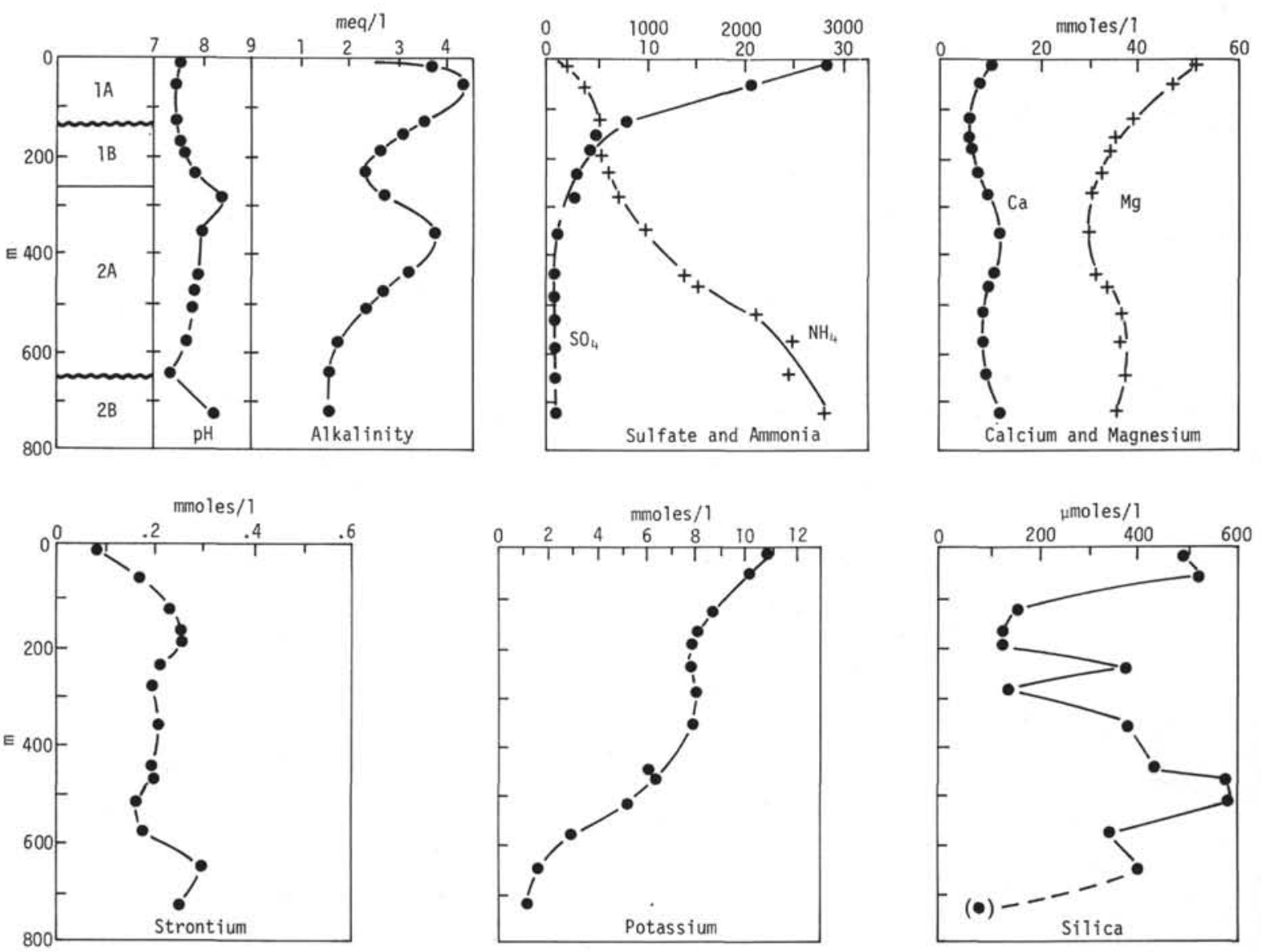

Figure 4. Interstitial water data, Site 368. Lithology: (1A) foram-bearing nanno marls and oozes; $(1 B)$ nanno oozes and marls, pelagic clay; (2A) cyclic interbeds (turbidites?) of green silty clays and claystones; $(2 B)$ interbedded green and red shales.
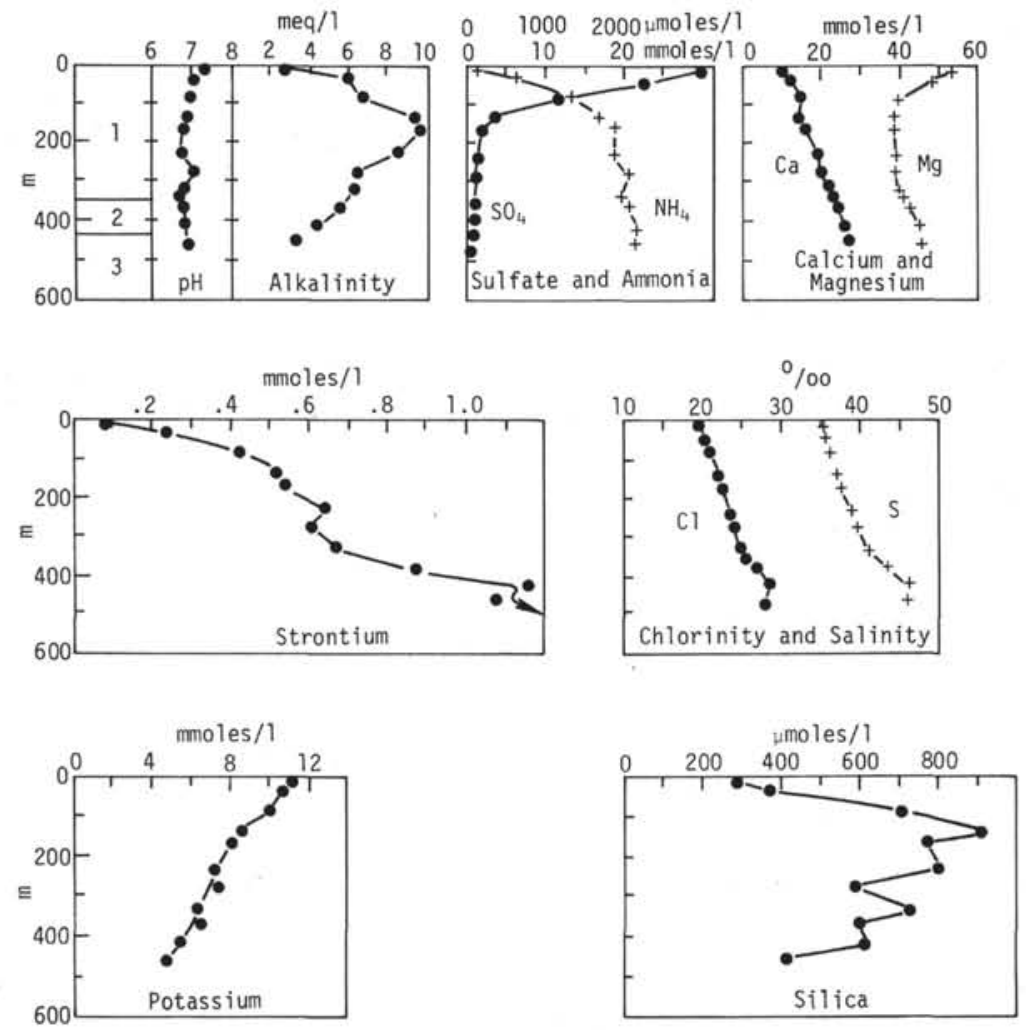

Figure 5. Interstitial water data, Site 369. Lithology: (1) nanno marls and siliceous nanno marls; (2) argillaceous limestones and chalks with cherts (346-394 m) and argillaceous marls and chalks (394-422 m); (3) silty nanno marls. 

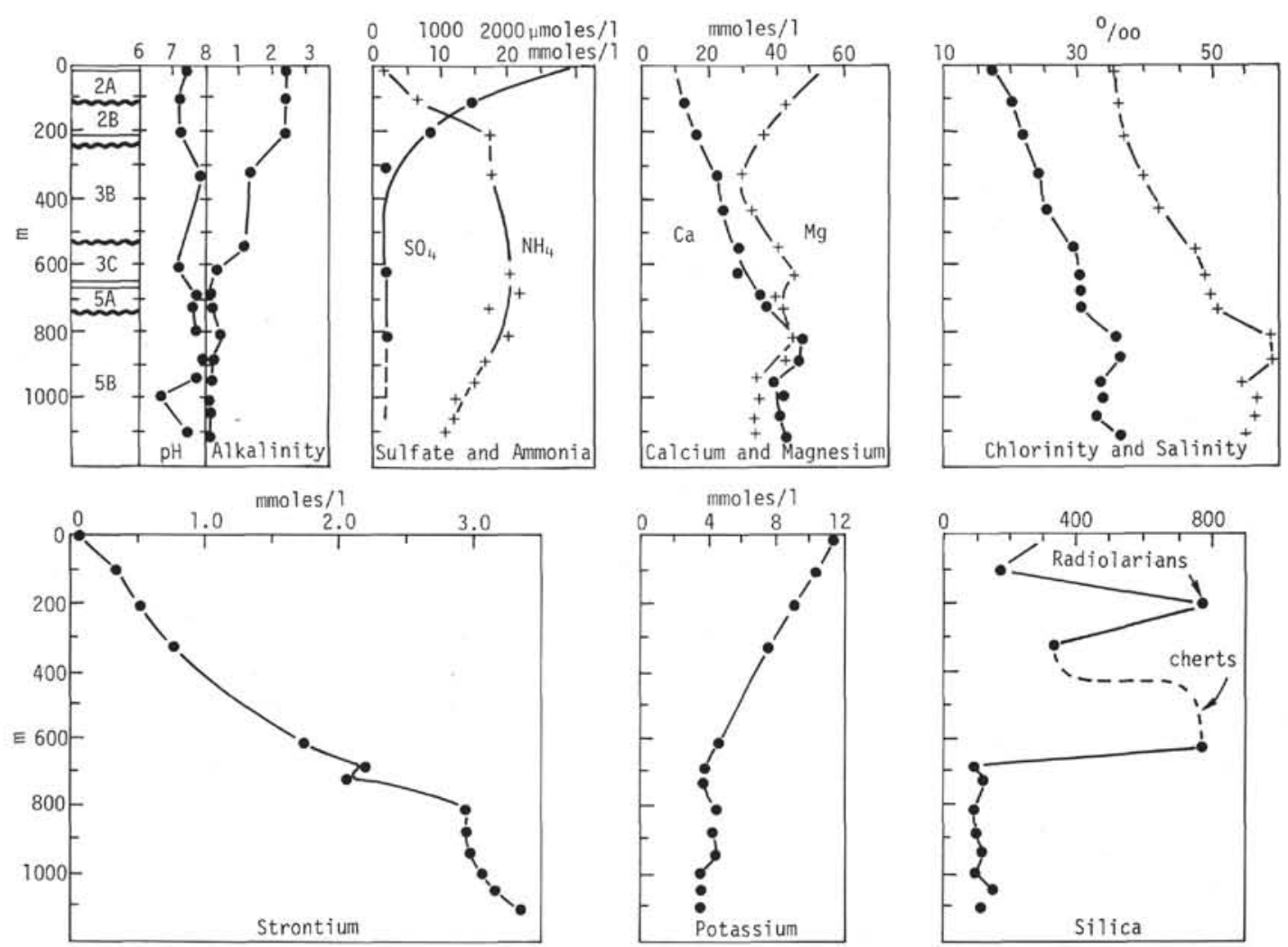

Figure 6. Interstitial water data, Site 370. Lithology: (1) nanno clay; (2A) clayey nanno ooze and marl; (2B) clayey nanno ooze with silts and sands; $(3 A)$ nanno radiolarian clay; $(3 B)$ calcareous silty clay with porcellanite; ( $3 C$ ) calcareous silty clay with silt, sand, porcellanite, and chert; (4) nanno marl; (5A) nanno-bearing claystone and claystone; (5B) calcareous claystones, siltstones, and sandstones.

those observed in cores reaching actual buried evaporites (Manheim and Sayles, 1974; McDuff et al., in press), so that underlying evaporites in the present area of investigation must occur at depths considerably below the deepest points drilled.

In the following we present a brief discussion of each site, individually.

\section{Site 366 (Figure 2)}

This site is characterized by sedimentation rates generally less than $2 \mathrm{~cm} / 1000 \mathrm{yr}$. The production of alkalinity and ammonia and the depletion of dissolved sulfate indicate a relatively small amount of bacteriological sulfate reduction in these sediments.

Increases in calcium and decreases in magnesium are moderate and show increased curvature with depth. Similar behavior is shown by strontium. Data from Hole 366A are somewhat offset from Site 366 (Table 1), but generally the data of this site are adequately represented in Figure 2. Throughout Site $366 \mathrm{Ca}^{++}$and $\mathrm{Mg}^{++}$are linearly correlated, with $\Delta \mathrm{Ca} / \Delta \mathrm{Mg}=1.1$. A similarly good correlation in Hole $366 \mathrm{~A}$ yields $\Delta \mathrm{Ca} / \Delta \mathrm{Mg}=1.4$. Also, below $130 \mathrm{~m}$, i.e., below Unit 1, a linear correlation exists between $\mathrm{Ca}^{++}$and $\mathrm{Sr}^{++}$, with $\Delta \mathrm{Sr} / \Delta \mathrm{Ca}=340 \times 10^{-4}$. The curvatures of the concentration depth profiles indicate the presence of at least two reaction zones (Kastner and Gieskes, 1976), one centered around 200 meters and one below the section cored, or in the deeper cored section.
If the observed alkaline earth concentration gradients are due to carbonate recrystallization reactions, and if magnesium is involved in the formation of dolomite, only relatively small amounts of dolomite would be formed and most of the carbonate would be recrystallized calcite. This can easily be deduced from the observed ratio $\Delta \mathrm{Sr} / \Delta \mathrm{Ca}=340 \times 10^{-4}$, which is considerably larger than the $\mathrm{Sr} / \mathrm{Ca}$ ratio of typical nanno oozes $\left(20 \times 10^{-4}\right)$. This point has been stressed before (Manheim and Sayles, 1974), and a correlation between strontium and magnesium has often been observed, but this correlation need not necessarily imply that magnesium is involved in carbonate diagenesis (Sayles and Manheim, 1975). The reaction zones appear to be located in those horizons where dissolved silica values are maximal. Perhaps diagenetic processes involving opaline silica are responsible for the observed changes in dissolved calcium and magnesium.

Decreases in dissolved potassium are generally very small and need no further comment here.

\section{Site 367 (Figure 3)}

At this site, the first 160 meters are characterized by very high sedimentation rates $(>9 \mathrm{~cm} / 1000 \mathrm{yr})$, but below this, sedimentation rates have been much lower $(<2 \mathrm{~cm} / 1000 \mathrm{yr})$. As can be expected in sediments with high sedimentation rates, the dissolved sulfate decreases to very low values, but most of this decrease appears to have its cause in the sediments below 600 
TABLE 2

X-Ray Diffraction Analyses, Leg 41

\begin{tabular}{|c|c|c|c|c|c|c|c|c|c|}
\hline Sample & $\begin{array}{l}\text { Depth } \\
\text { (m) }\end{array}$ & Age & & 气 & 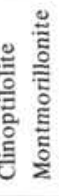 & 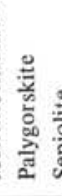 & & & 总 \\
\hline $366-14 A-5(144-150)$ & 128 & U. Miocene & & 2 & 2 & & & 1 & \\
\hline$-5-5(142-150)$ & 374 & L. Oligocene & 1 & 1 & 2 & & & 2 & \\
\hline$-20-1(145-150)$ & 510 & M. Eocene & & & 2 & & & 2 & \\
\hline $367-4-4(144-150)$ & 70 & Pliocene & 1 & 1 & & & & 1 & \\
\hline$-8-4$ & 309 & U. Eocene & 1 & & & & 3 & & \\
\hline$-14-2$ & 382 & L. Eocene & & & 22 & & & & \\
\hline$-15-4$ & 480 & U. Cret.-Pal. & 1 & 2 & 2 & 1 & & & \\
\hline$-16-5(140-150)$ & 548 & U. Cret. & 1 & 1 & 2 & 1 & & & \\
\hline$-23-1$ & 779 & Apt.-Alb. & & 2 & 2 & & & & \\
\hline $368-1-4(1440150)$ & 4 & Quaternary & & 2 & & & & - & \\
\hline$-3-4(0-6)$ & 52 & Pleistocene & 2 & 2 & 1 & & & 2 & \\
\hline$-6-5(144-150)$ & 166 & U. Miocene & 2 & 2 & 2 & 1 & & 2 & \\
\hline$-8-4$ & 185 & U. Miocene & & 2 & & & & - & \\
\hline$-13-2$ & 232 & M. Miocene & & 2 & 2 & & & 2 & \\
\hline$-18-5$ & 280 & L. Miocene & 1 & 2 & 1 & 1 & & & \\
\hline$-23-1$ & 356 & ?M. Eo.-L. Mio. & & & & 3 & & & \\
\hline$-23-1$ (Greenish & 356 & ?M. Eo.-L. Mio. & & 1 & 2 & 21 & 1 & 1 & \\
\hline layer in same sample) & & & & & & & & & \\
\hline$-32-4$ & 441 & L.-M. Eocene & & 1 & & 3 & 1 & & \\
\hline $368-34-2(144-150)$ & 470 & L.-M. Eocene & & & & 3 & & & \\
\hline$-36-2$ & 517 & L.-M. Eocene & & & & 2 & 2 & & \\
\hline$-39-5$ & 574 & L. Eo-U. Pal. & & & 1 & 2 & 2 & & \\
\hline$-42-2$ & 601 & U. Pal-U. Cret. & & & & 2 & 1 & & 2 \\
\hline$-46-4$ & 641 & U. Pal.-U. Cret. & & & 2 & 1 & & & \\
\hline$-52-4$ & 726 & Pal.?-U. Cret. & 1 & & 2 & 1 & & & \\
\hline $.55-2$ & 841 & U. Cretaceous & & & & 3 & & & 1 \\
\hline $369-5-4(144-150)$ & 38 & L. Plio-U, Mio. & 2 & 2 & & & & 2 & \\
\hline$-5 \mathrm{~A}-5$ & 88 & M. Miocene & - & - & - & - & - & & \\
\hline$-14 \mathrm{~A}-5$ & 163 & Oligocene & & 2 & & & & 2 & 1 \\
\hline$-35 \mathrm{~A}-3$ & 370 & M. Eocene & 1 & & 22 & 1 & & & 2 \\
\hline$-40 \mathrm{~A}-2$ & 416 & Con.-Santonian & & & & 2 & & 2 & 1 \\
\hline$-44 \mathrm{~A}-1$ & 452 & Albian-Aptian & 2 & 1 & 1 & 2 & & & \\
\hline $370-3-1(144-150)$ & 209 & M. Miocene & 2 & 2 & & 1 & & 2 & 1 \\
\hline$-5-5$ & 329 & Oligocene & 2 & 1 & & 1 & & $i$ & 2 \\
\hline$-6-2$ & 429 & U. Eocene & 1 & 1 & 1 & 1 & & 1 & 1 \\
\hline & & M. Eocene & 2 & 2 & & 2 & & 2 & 2 \\
\hline$-17-2$ & 620 & L. Eocene & & & & 2 & 1 & - & - - \\
\hline$-20-2$ & 680 & Cenom.-Albian & & 1 & 2 & & & & \\
\hline$-34-3$ & 880 & Neocomian & & 2 & & 2 & & 2 & 1 \\
\hline$-44-2$ & 1050 & Neocomian & 2 & 2 & & 1 ? & & & \\
\hline$-47-1$ & 1105 & Neocomian & 2 & 2 & & & & $1-$ & -- \\
\hline
\end{tabular}

Note: $1=$ present $; 2=$ abundant; 3 = consists almost all of the clay fraction; $-=$ not determined

meters, where very high organic carbon contents have been observed. Paucity of data to a depth of 300 meters, however, does not allow a precise description of the dissolved sulfate profile. Ammonia data reflect fairly well the sulfate profile.

Dissolved calcium shows a slight minimum in the upper part of the hole, followed by a gradual increase with depth. Decreases in magnesium are small. Dissolved strontium probably reflects recrystallization processes occurring in the Neocomian limestones below 850 meters. It appears that the dissolved strontium profile above 800 meters reflects essentially a diffusion profile much like that observed at Site 323 of Leg 35 (Gieskes and Lawrence, 1976; McDuff and Gieskes, 1976).

The data for dissolved potassium suggest a sink in the sediments below 500 meters. Charge balance calculations show that sodium is reduced by up to $20 \%$ below 500 meters. We have insufficient information to identify the sink completely, but montmorillonite appears to be the main sodium-containing mineral.

Dissolved silica is high only where opaline silica is present in the sediments, e.g., in Core 367-8. Sediment from this core consists almost entirely of sepiolite, and at this point there is a maximum in alkalinity and perhaps total $\mathrm{CO}_{2}$. It is likely that the alkalinity produced by sulfate reduction, together with the dissolution of opaline silica, still creates an environment favorable to sepiolite precipitation.

\section{Site 368 (Figure 4)}

Sedimentation rates of Units $1 \mathrm{a}$ and $1 \mathrm{~b}$ have been 2-3 $\mathrm{cm} / 1000 \mathrm{yr}$, whereas the underlying sediments were deposited at much slower rates. Organic carbon data collected onboard ship indicate increased levels below 320 meters, with particularly high values in the black shales below 900 meters. Usually moderate decreases in dissolved sulfate accompany sedimentation rates of 2-3 $\mathrm{cm} / 1000 \mathrm{yr}$, but in these sediments of high organic carbon contents, sulfate reduction rates are sufficiently high to cause virtually complete sulfate depletion below 300 meters. In the lower horizons, methane gas becomes increasingly important, and this is reflected in the continuous increase in dissolved ammonia.

Of some note are the maxima in alkalinity and calcium at 350 meters. These extrema coincide with a minimum in magnesium. Palygorskite dominates the mineralogy from 350 meters to 500 meters, and from 500 meters to 600 meters both palygorskite and sepiolite are most prominent. Continuing formation of these authigenic minerals around 350 meters is consistent with the observations in the interstitial water data. The increase in calcium is probably related to calcium carbonate dissolution processes in these horizons.

\section{Site 369 (Figure 5)}

Sedimentation rates in this hole have generally been very slow, but again high organic carbon contents have led to a very large depletion in dissolved sulfate within the upper 200 meters. The maximum rate of reaction appears to occur at about 150-180 meters in the section where radiolarian silica occurs in large quantities (cf., dissolved silica profile).

Calcium values increase throughout the sediment column; magnesium, however, does again show a broad minimum. The minimum appears to coincide roughly with the appearance of palygorskite and montmorillonite. However, explanations cannot be straightforward without additional information on the mineralogy.

Dissolved strontium increases throughout the section and is probably a result of carbonate recrystallization. In the deeper section, shipboard observations indicated the replacement of gypsum rosettes by calcite. Perhaps calcium-rich solutions did precipitate this mineral during Cretaceous times, probably related to an upward migration from underlying evaporite beds. Subsequent reduction of sulfate may have caused dissolution of this gypsum and precipitation of authigenic carbonate. If this is so, the carbonate ions are presumably of biogenic origin, which can be tested by determining the $\mathrm{C}^{13} / \mathrm{C}^{12}$ ratio, which should be light (cf., Anderson and Lawrence, 1976).

\section{Site 370 (Figure 6)}

Again, sulfate depletions are large in this hole, but they are not accompanied by an alkalinity increase. 
This is an important observation because it implies a significant sink for alkalinity $\left(\mathrm{HCO}_{3}{ }^{-}\right)$in these sediments.

The calcium values, again, increase throughout this hole, and magnesium shows a distinct minimum at 350 meters. Dissolved strontium reaches very large values at this site.

In the meantime, careful mineralogical work on this site may reveal some features that can be linked to the present interstitial water observations. Palygorskite again is a rather common mineral in this site.

Of some note is the relative constancy of chlorinity and salinity in Unit 5b. Perhaps horizontal diffusion or advection through the sandstone layers may be responsible for this. Again, the nearby site which may be drilled during Leg 50 may be relevant to this.

\section{ACKNOWLEDGMENTS}

We wish to thank Mr. Denis Graham, the shipboard chemist, for his diligent shipboard analyses. This work was supported by NSF Grant DES 72-01410.

\section{REFERENCES}

Anderson, T.F. and Lawrence, J.R., 1976. Stable isotope investigations of sediments, basalts, and authigenic phases from Leg 35 cores. In Hollister, C. D., Craddock, C., et al., Initial Reports of the Deep Sea Drilling Project, Volume 35: Washington (U.S. Government Printing Office), p. 497-505.
Gieskes, J.M., 1974. Interstitial water studies, Leg 25. In Simpson, E.S.W., Schlich, R., et al., Initial Reports of the Deep Sea Drilling Project, Volume 25: Washington (U.S. Government Printing Office), p. 361-394.

Gieskes, J.M. and Lawrence, J.R., 1976. Interstitial water studies, Leg 35. In Hollister, C.D., Craddock, C., et al., Initial Reports of the Deep Sea Drilling Project, Volume 35: Washington (U.S. Government Printing Office), p. 407-424.

Kastner, M. and Gieskes, J.M., 1976. Interstitial water profiles and sites of diagenetic reactions, Leg 35, DSDP, Bellingshausen Abyssal Plain: Earth Planet. Sci. Lett., v. 33 , p. 11-20.

Manheim, F.T. and Sayles, F.L., 1974. Composition and origin of interstitial waters of marine sediments, based on deep sea drill cores. In Goldberg, E.D. (Ed.), The Sea, v. 5: New York (Wiley-Interscience), p. 527-568.

McDuff, R.E. and Gieskes, J.M., 1976. Calcium and magnesium profiles in DSDP interstitial waters: diffusion or reaction?: Earth Planet. Sci. Lett., v. 33, p. 1-10.

McDuff, R.E., Lawrence, J.R., and Gieskes, J.M., in press. Interstitial water analyses, Leg $42 \mathrm{~A}$. In Hsü, K. et al., Initial Reports of the Deep Sea Drilling Project, Volume 42: Washington (U.S. Government Printing Office).

Sayles, F.L. and Manheim, F.T., 1975. Interstitial solutions and diagenesis in deeply buried marine sediments: Results from the Deep Sea Drilling Project: Geochim. Cosmochim. Acta, v. 39, p. 103-127.

Waterman, L.S., Sayles, F.L., and Manheim, F.T., 1972. Interstitial water studies on small core samples, Leg 14. In Hayes, D.E. et al., Initial Reports of the Deep Sea Drilling Project, Volume 14: Washington (U.S. Government Printing Office), p. 753-762. 